\title{
摇動あるいは鲶旋回時における弾性支持ロータの振動解析*
}

\author{
坂田勝*1, 木 村 康 治*1 \\ 岡 本 伸 吾*2, 及川和 亮*3

\section{Vibration Analysis of a Rotor on a Flexible Suspension Subjected to Pitching or Quick Turn Motion}

\author{
Masaru SAKATA, Koji KIMURA, \\ Shingo OKAMOTO and Kazuaki OIKAWA
}

\begin{abstract}
High speed rotors in jet engines or turbopumps used in space vehicles are mostly operated at a supercritical speed and their bearings and housings are usually supported elastically from the frame in order to reduce critical speeds. However, when the aircraft or the space vehicle turns or responds to disturbances, the rotor may contact with the casing due to vibration caused by gyroscopic moment. In this paper, a dynamic analysis is performed on vibration of a mechanical system subjected to pitching motion of the frame. Flexibility and mass of bearing housings are taken into account and the axis of pitching motion is assumed to be distant from the center of mass of the rotor. The usefulness of modeling and the validity of the computational program are demonstrated by comparison with the experimental results obtained using a model rotor. The dynamic response of the system in case of quick turn is also calculated.
\end{abstract}

Key Words: Vibration of Rotating Body, Rotordynamics, Elastic Bearing Support. Base Excitation. Pitching Motion, Gyroscopic Moment

\section{1. 緒}

ジェットエンジンやロケット用ターボポンプなどに 用いられる高速ロータは，通常，危険速度以上で使用 されるため, 危険速度を速やかに通過することが要求 される。したがって，危険速度を下げて設計すること があり，軸受支持部は弾性的に支持される場合が多 い. 航空機やロケットが旋回，摇動(機体重心回りの回 転運動)なよ゙により基礎励振を受ける場合は、このよ うなロータはジャイロ効果による摇動を生じやすく， ロータとケーシングが接触したり，軸受が損傷する危 険性がある。また，地震動を受ける発電プラントにつ いても同様な問題が生じる。したがって, 基礎励振を 受けるロータの振動を予測することは設計上重要であ るから，基礎が並進運動する場合(1)-(6)，摇動する場 合(5)(6)についていくつかの研究が報告されている. Soni ら (5)は，弾性支持された岡性ロー夕が基礎励振を 受ける場合の地震応答解析を行っている。また，著者 ら (7)は単純支持された弾性ロー夕が旋回する場合の定

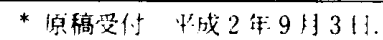

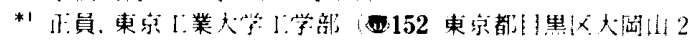
12-1\%.

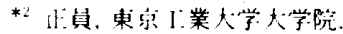

*:1 東京 I: 業大学大学院.
}

常応答解析を行い，実験結果と比較検討している。し かし，ロケットに搭載された燃料ポンプなどでは，口 ー夕の設置位置と摇動運動の中心軸との距離が振動に 影響を及ほすが、このような場合の研究は見当たら ない，また，従来の研究では弾性支持部は軸受あるい は軸受台のみの弾性と粘性隇衰によってモデル化され ており，軸受および軸受台の質量の効果は無視され ている.

本研究では，質量を有する軸受台によって弾性的 に支持された剛性ロー夕が摇動中心からある距離だけ 離れた位置に設置された場合を想定し、Soniらが導 いた式よりも一般的な運動方程式を導出し, 固有值と 摇動時の応答の解析を行った。また本解析のモデル化 と解析プログラムの有効性を確かめるために摇動実験 を行い，解析結果と実験結果上を比較検討した。さう に,このプログラムを用いて急旋回時の応答解析を行 った.

\section{2. 理 論 解 析}

$2 \cdot 1$ 解析モテル ロータの不釣合い量は微小と し，解析では不釣合いの影響は無視する。図1に解析 モデルを示す．回転円板を取付けた剛性回転軸の両端 は弾性を有する軸受によって支持され，さらに軸受台 
はフレームに対して弾性支持されている。フレームは

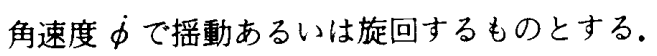

$2 \cdot 2$ 座標系の定我 図 1,2 に示す座標系を用 いる.

（1） $0-X Y Z$ 座標系(静止座標系) 静止座標 系の $Z$ 軸と静止しているロータの回転軸の中心線を 一致させる。原点 $\mathrm{O}$ は摇動・旋回軸 $Y$ と静止している ときのロータの回転軸 $Z$ との交点である． $X Y Z$ 方向 の単位べクトルを $\{\boldsymbol{I}, \boldsymbol{J}, \boldsymbol{K}\}$ とする.

(2) O- $x y z$ 座標系(フレームに固定された摇動・ 旋回座標系）摇動・旋回により静止座標系が $Y$ 軸

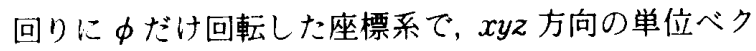
トルを $\{\boldsymbol{i}, \boldsymbol{j}, \boldsymbol{k}\}$ とする $(\boldsymbol{j}=\boldsymbol{J})$.

(3) $\mathrm{G}-x^{\prime} y^{\prime} z^{\prime}$ 座標系 $\quad \mathrm{O}-x y z$ 座標系の $z=l_{G} に$ あったロー夕の重心が支持部の弾性変形により $x y$ 平 面内を点 $\mathrm{G} に$ 移動する。この場合の重心 $\mathrm{G}$ を原点とす る座標系で, $x^{\prime} y^{\prime} z^{\prime}$ 方向の単位ベクトルを $\{\boldsymbol{i}, \boldsymbol{j}, \boldsymbol{k}\}$ と する。

（4） G- $\xi y^{\prime} z^{\prime \prime}$ 座標系支持部の弾性変形により $\mathrm{G}-x^{\prime} y^{\prime} z^{\prime}$ 座標系が $y^{\prime}$ 軸回りに $\theta_{y}$ 回転した座標系で, $\xi y^{\prime} z^{\prime \prime}$ 方向の単位べクトルを $\left\{\boldsymbol{e}_{\boldsymbol{\varepsilon}}, \boldsymbol{j}, \boldsymbol{k}^{\prime}\right\}$ とする.

(5) $\mathrm{G}-\xi \eta \zeta$ 座標系(振れ回り運動に固定された座 標系）支持部の弾性変形により $G-\xi y^{\prime} z^{\prime \prime}$ 座標系が $\xi$ 軸回りに $\theta_{\xi}$ 回転した座標系で, $\xi \eta \zeta$ 方向の単位べク トルを $\left\{e_{\xi}, e_{\eta}, e_{\xi}\right\}$ とする.

$2 \cdot 3$ 絶対速度摇動あるいは旋回時に支持部が弾 性変形し, $z=l_{G}$ にあった口ー夕の重心が $x y$ 平面内 を移動し点 $\mathrm{G}$ に移った場合, 点 $\mathrm{G}$ の絶対速度 $V_{G}$ は,

$$
\boldsymbol{V}_{G}=\frac{d}{d t} \boldsymbol{R}_{G}+\omega \times \boldsymbol{R}_{C}
$$

で表される(8).ここで， $\boldsymbol{R}_{G}$ は O- $x y z$ 座標系における 重心 $\mathrm{G}$ の位置べクトルであり，

$$
\boldsymbol{R}_{G}=x_{G} \boldsymbol{i}+y_{G} \boldsymbol{j}+l_{G} \boldsymbol{k}
$$

で表される。また $\omega$ は $\mathrm{O}^{-} x y z$ 座標系が $\mathrm{O}-X Y Z$ 座標

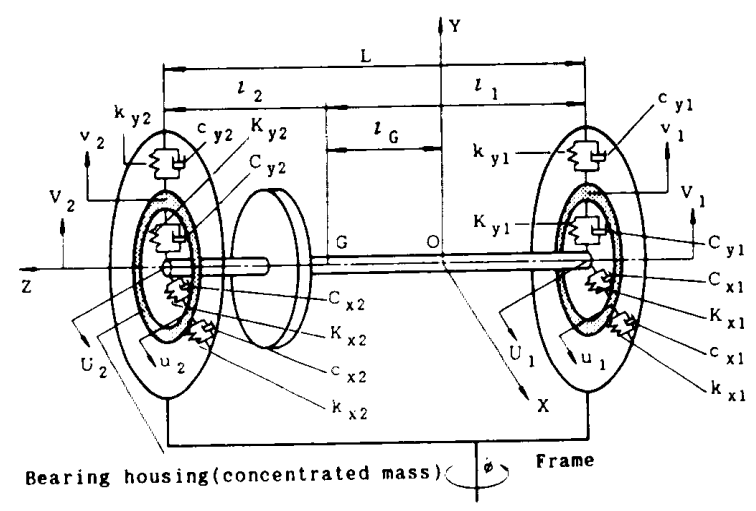

図 1 解析モデル
系に対して摇動・旋回した場合の回転角速度べクトル であり,

$$
\boldsymbol{\omega}=\dot{\phi} \boldsymbol{j}
$$

で表される.したがって、式 (2)と（3)を式（1）に代 入すると $\boldsymbol{V}_{G}$ は，

$$
\boldsymbol{V}_{G}=\left(l_{C} \dot{\phi}+\dot{x}_{G}\right) \boldsymbol{i}+\dot{y}_{G} \boldsymbol{j}-x_{G} \dot{\phi} \boldsymbol{k}
$$

となる.

さらに，ロータが回転角速度 $\Omega$ で回転している場 合， $\mathrm{G}-\xi \eta \zeta$ 座標系におけるロータ内の任意点 $\mathrm{p}$ の絶 対速度 $V_{P}$ は,

$$
\boldsymbol{V}_{P}=\boldsymbol{V}_{G}+\frac{d}{d t} \boldsymbol{R}_{p}+\left(\omega+\omega^{\prime}\right) \times \boldsymbol{R}_{P}
$$

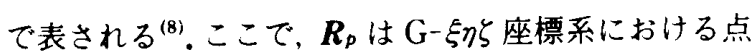
$\mathrm{p}$ の位置ベクトルであり, 円筒座標系 $(r, \alpha, \zeta)$ を用い ると次式で表される。

$$
\begin{aligned}
\boldsymbol{R}_{p} & =\{r \cos (\beta+\alpha)\} \boldsymbol{e}_{\xi} \\
& +\{r \sin (\beta+\alpha)\} \boldsymbol{e}_{\eta}+\zeta \boldsymbol{e}_{\xi}
\end{aligned}
$$

ここで， $\beta=\Omega t+\delta$ で表され， $\delta$ は初期位相である.ま た, $\omega^{\prime}$ は支持部の弾性変形により $\mathrm{G}-\xi \eta \zeta$ 座標系が $\mathrm{G}-$ $x^{\prime} y^{\prime} z^{\prime}$ 座標系に対して回転した場合の回転角速度べク トルである、G- $\xi y^{\prime} z^{\prime \prime}$ 座標系の $\mathrm{G}-x^{\prime} y^{\prime} z^{\prime}$ 座標系に対す る回転角速度ベクトルを

$$
\dot{\boldsymbol{\theta}}_{y}=\dot{\theta}_{y} \boldsymbol{j}
$$

とし, G- $\xi \eta \zeta$ 座標系の G- $\xi y^{\prime} z^{\prime \prime}$ 座標系に対する回転 角速度ベクトルを

$$
\dot{\theta}_{\xi}=\dot{\theta}_{\xi} e_{\xi}
$$

とすると, $\omega^{\prime}$ は、

$$
\begin{aligned}
\omega^{\prime} & =\dot{\theta}_{\xi} e_{\xi}+\dot{\theta}_{\eta} e_{\eta}+\dot{\theta}_{\xi} e_{\zeta} \\
& =\dot{\theta}_{\varepsilon} e_{\xi}+\left(\dot{\theta}_{y} \cos \theta_{\xi}\right) e_{\eta}-\left(\dot{\theta}_{y} \sin \theta_{\varepsilon}\right) e_{\zeta}
\end{aligned}
$$

で表される.ここで， $\theta_{y} ， \theta_{\xi}$ は微小とし

$$
\theta_{x}=\theta_{\xi} \cos \theta_{y} \fallingdotseq \theta_{\xi}
$$

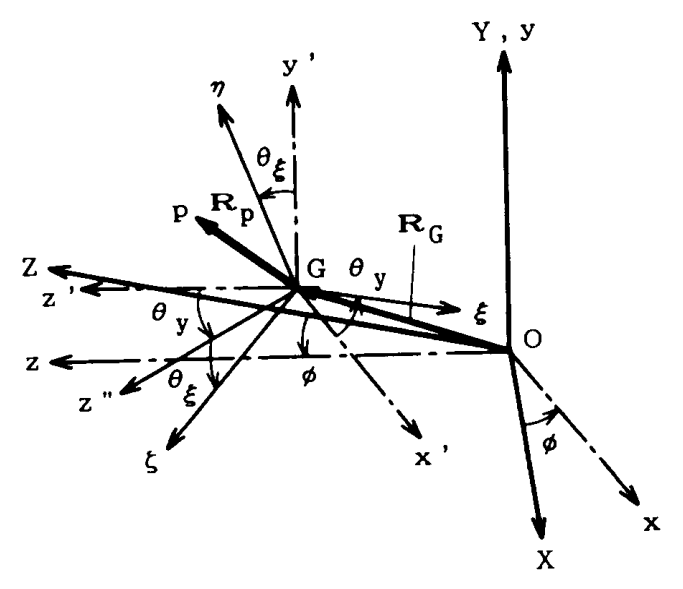

図 2 座標系の相対運動 
を考虑すると式 $(9)$ は,

$$
\boldsymbol{\omega}^{\prime}=\dot{\theta}_{x} \boldsymbol{e}_{\xi}+\dot{\theta}_{y} \boldsymbol{e}_{\eta}-\dot{\theta}_{y} \theta_{x} \boldsymbol{e}_{\zeta}
$$

で近以できる。また，O- $x y z$ 座標系の成分で表された

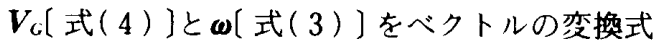

$$
\left\{\begin{array}{l}
e_{\xi} \\
e_{\eta} \\
e_{\xi}
\end{array}\right\}=\left(\begin{array}{rrr}
1 & 0 & -\theta_{y} \\
0 & 1 & \theta_{x} \\
\theta_{y} & -\theta_{x} & 1
\end{array}\right)\left\{\begin{array}{l}
\boldsymbol{i} \\
j \\
k
\end{array}\right\}
$$

を用いて，G- $\xi \eta \zeta$ 座標系の成分で表されたベクトルに 変換して式(5)に代入すれば, 結局 $V_{p}$ は，次式で表 される。

$$
\begin{aligned}
& V_{p}=V_{p q} e_{\xi}+V_{p \eta} e_{\eta}+V_{p \zeta} e_{\zeta} \\
& V_{P \xi}=l_{G} \dot{\phi}+\dot{x}_{G}+x_{G} \theta_{y} \dot{\phi}-r \Omega \sin (\beta+\alpha) \\
& +r\left(\dot{\phi}+\dot{\theta}_{y}\right) \theta_{x} \sin (\beta+\alpha)+\left(\dot{\phi}+\dot{\theta}_{y}\right) \zeta \\
& \ldots \ldots \ldots \ldots \ldots \ldots \ldots \\
& V_{p \eta}=\dot{y}_{G}-x_{G} \theta_{x} \dot{\phi}+r \Omega \cos (\beta+\alpha) \\
& -r\left(\dot{\phi}+\dot{\theta}_{y}\right) \theta_{x} \cos (\beta+\alpha)-\dot{\theta}_{x} \zeta \ldots \ldots \ldots \ldots \\
& V_{p \zeta}=l_{C} \dot{\phi} \theta_{y}+\dot{x}_{G} \theta_{y}-\dot{y}_{c} \theta_{x}-x_{C} \dot{\phi} \\
& \quad+r \dot{\theta}_{x} \sin (\beta+\alpha)-r\left(\dot{\phi}+\dot{\theta}_{y}\right) \cos (\beta+\alpha)
\end{aligned}
$$

2.4 通動エネルギー 回転軸と回転円板からな るロータの運動エネルギーおよび軸受と軸受台を集中 質量でモデル化した支持部の運動エネルギーを求め る.

$$
\text { （1）ロータの運動エネルギー ロータの運動工 }
$$
ネルギーは次式で与えられる。

$$
T_{R}=\frac{1}{2} \rho \iiint\left|v_{p}\right|^{2} r \mathrm{~d} r \mathrm{~d} \alpha \mathrm{d} \zeta
$$

ここで，ロータの質量を $M$, ロー夕の主軸すなわち $\zeta$ 軸に関する主慣性モーメントを $J_{P}$, 軸対称な形状を仮 定し $\xi$ 軸 $\eta$ 軸に関する慣性モーメントを $J_{d}$ とすると

$$
\begin{aligned}
& M=\rho \iiint r \mathrm{~d} r \mathrm{~d} \alpha \mathrm{d} \zeta \\
& J_{\rho}=\rho \iiint r^{2} r \mathrm{~d} r \mathrm{~d} \alpha \mathrm{d} \zeta \\
& J_{d}=\rho \iiint\left\{r^{2} \sin ^{2}(\beta+\alpha)+\zeta^{2}\right\} r \mathrm{~d} r \mathrm{~d} \alpha \mathrm{d} \zeta \\
& =\rho \iiint\left\{r^{2} \cos ^{2}(\beta+\alpha)+\zeta^{2}\right\} r \mathrm{~d} r \mathrm{~d} \alpha \mathrm{d} \zeta
\end{aligned}
$$

となる.また，図1に示すように，両軸受のある位置で の回転軸の $x$ 方向相対変位をそれぞれ $U_{1}, U_{2}, y$ 方向 相対変位を $V_{1}, V_{2}$ とすると重心 $\mathrm{G}$ の座標とロー夕の 回転角 $x_{G}, y_{C}, \theta_{x}, \theta_{y}$ は，

$$
\begin{aligned}
& x_{C}=\frac{l_{2}}{L} U_{1}+\frac{l_{1}}{L} U_{2} \\
& y_{C}=\frac{l_{2}}{L} V_{1}+\frac{l_{1}}{L} V_{2} \\
& \theta_{x}=\frac{V_{1}-V_{2}}{L} \ldots . . \\
& \theta_{y}=\frac{U_{2}-U_{1}}{L} \ldots . .
\end{aligned}
$$

で表される.したがって，式(13)〜(16)，式(18)～(24) を式(17)に代入するとロータの運動エネルギーは次式 となる。

$$
\begin{aligned}
& T_{R}=\frac{M}{2 L^{2}}\left\{l_{1} l_{2} \dot{U}_{1}^{2}+l_{1} l_{2} \dot{U}_{2}^{2}+\left(l_{1}^{2}+l_{2}^{2}\right) \dot{U}_{1} \dot{U}_{2}\right\}+\frac{M}{2 L^{2}}\left\{l_{1} l_{2} \dot{V}_{1}^{2}+l_{1} l_{2} \dot{V}_{2}^{2}+\left(l_{1}^{2}+l_{2}^{2}\right) \dot{V}_{1} \dot{V}_{2}\right\} \\
& +\frac{J_{d}}{2 L^{2}}\left(\dot{U}_{1}^{2}+\dot{U}_{2}^{2}-2 \dot{U}_{1} \dot{U}_{2}\right)+\frac{J_{d}}{2 L^{2}}\left(\dot{V}_{1}^{2}+\dot{V}_{2}^{2}-2 \dot{V}_{1} \dot{V}_{2}\right)-\frac{\Omega J_{p}}{L^{2}}\left(\dot{U}_{1} V_{2}-\dot{U}_{1} V_{1}+\dot{U}_{2} V_{1}-\dot{U}_{2} V_{2}\right) \\
& \left.\left.-\frac{\Omega J_{\rho} \dot{\phi}}{L}\left(V_{1}-V_{2}\right)-\frac{J_{d} \dot{\phi}}{L}\left(\dot{U}_{1}-\dot{U}_{2}\right)+\frac{M \dot{\phi}}{2 L}\right)\left\{l_{G}\left(l_{1}+l_{2}\right)-l_{2}\left(l_{1}-l_{2}\right)\right\} \dot{U}_{1}+\left\{l_{C}\left(l_{1}+l_{2}\right)-l_{1}\left(l_{1}-l_{2}\right)\right\} \dot{U}_{2}\right) \\
& +\frac{M \dot{\phi}^{2}}{2 \bar{L}^{2}}\left\{\left(l_{1} l_{2}+l_{G}^{2}\right)\left(U_{1}^{2}+U_{2}^{2}\right)+\left(l_{1}^{2}+l_{2}^{2}-2 l_{G}^{2}\right) U_{1} U_{2}\right\}+\frac{J_{p} \dot{\phi}^{2}}{2 L^{2}}\left(V_{1}^{2}+V_{2}^{2}-2 V_{1} V_{2}\right)
\end{aligned}
$$

ここで, $x_{c}, y_{c}, \theta_{x}, \theta_{y}, \dot{x}_{G}, \dot{y}_{c}, \dot{\theta}_{x}, \dot{\theta}_{y}$ を含まない項および 3 次以上の微小項は省略した。

（2）支持部の運動エネルギー 軸受および軸受台(支持部)の運動エネルギーを求める。両端支持部の集中質 量を $m_{1}, m_{2}$, フレームに対する $x$ 方向相対変位を $u_{1}, u_{2}, y$ 方向相対変位を $v_{1}, v_{2}$ とすると支持部の運動エネルギ 一は次式で表される.

$$
\begin{aligned}
& T_{1}=\frac{1}{2} m_{1} \dot{u}_{1}^{2}+\frac{1}{2} m_{1} \dot{v}_{1}^{2}-m_{1}\left(l_{1}-l_{C}\right) \dot{\phi} \dot{u}_{1}+\frac{1}{2} m_{1} \dot{\phi}^{2} u_{1}^{2} \\
& T_{2}=\frac{1}{2} m_{2} \dot{u}_{2}^{2}+\frac{1}{2} m_{2} \dot{v}_{2}^{2}+m_{2}\left(l_{C}+l_{2}\right) \dot{\phi} \dot{u}_{2}+\frac{1}{2} m_{2} \dot{\phi}^{2} u_{2}^{2}
\end{aligned}
$$

ここで,

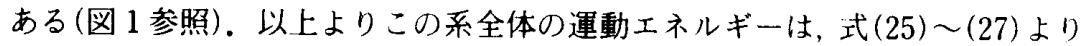

$$
T_{a}=T_{R}+T_{1}+T_{2}
$$

で表される。 
$x$ 方向, $y$ 方向のばね定数を $K_{x 1}, K_{y 1}, K_{x 2}, K_{y 2}$, 軸受台の $x$ 方向, $y$ 方向のばね定数を $k_{x 1}, k_{y 1}, k_{x 2}, k_{y 2}$ とするとポ テンシャルエネルギーは次式で表される。

$$
\begin{aligned}
E_{p} & =\frac{1}{2} K_{x 1}\left(U_{1}-u_{1}\right)^{2}+\frac{1}{2} k_{x 1} u_{1}^{2}+\frac{1}{2} K_{y 1}\left(V_{1}-v_{1}\right)^{2}+\frac{1}{2} k_{y 1} v_{1}^{2}+\frac{1}{2} K_{x 2}\left(U_{2}-u_{2}\right)^{2} \\
& +\frac{1}{2} k_{x 2} u_{2}^{2}+\frac{1}{2} K_{y 2}\left(V_{2}-v_{2}\right)^{2}+\frac{1}{2} k_{y 2} v_{2}^{2} \ldots \ldots \ldots \ldots \ldots \ldots \ldots \ldots \ldots \ldots \ldots \ldots \ldots \ldots \ldots \ldots \ldots \ldots \ldots \ldots \ldots \ldots \ldots \ldots \ldots \ldots \ldots \ldots \ldots \ldots \ldots \ldots \ldots \ldots
\end{aligned}
$$

$2 \cdot 6$ 散逸エネルギー 2 個の軸受の $x$ 方向, $y$ 方向の粘性隇衰係数をそれぞれ $C_{x 1}, C_{y 1}, C_{x 2}, C_{y 2}, 2$ 個の軸受 台の $x$ 方向, $y$ 方向の粘性隇衰係数をそれぞれ $c_{x 1}, c_{y 1}, c_{x 2}, c_{y 2}$ で表すと散逸エネルギーは次式で表される.

$$
\begin{aligned}
& F=\frac{1}{2} C_{x 1}\left(\dot{U}_{1}-\dot{u}_{1}\right)^{2}+\frac{1}{2} c_{x 1} \dot{u}_{1}^{2}+\frac{1}{2} C_{y 1}\left(\dot{V}_{1}-\dot{v}_{1}\right)^{2}+\frac{1}{2} c_{y 1} \dot{v}_{1}^{2}+\frac{1}{2} C_{x 2}\left(\dot{U}_{2}-\dot{u}_{2}\right)^{2}+\frac{1}{2} c_{x 2} \dot{u}_{2}^{2} \\
& +\frac{1}{2} C_{y 2}\left(\dot{V}_{2}-\dot{v}_{2}\right)^{2}+\frac{1}{2} c_{y 2} \dot{v}_{2}^{2}
\end{aligned}
$$

$2 \cdot 7$ 運椁方程式系全体の運動エネルギーの式 (25) （28）, ポテンシャルエネルギーの式(29), 散逸 エネルギーの式(30)を用いてラグランジュ方程式を求 めることができる。

$$
\begin{gathered}
\frac{d}{d t}\left(\frac{\partial T_{a}}{\partial \dot{q}_{i}}\right)-\frac{\partial T_{a}}{\partial q_{i}}+\frac{\partial F}{\partial \dot{q}_{i}}+\frac{\partial E_{p}}{\partial q_{i}}=0 \\
(i=1 \sim 8)
\end{gathered}
$$

ここで， $q_{i}$ は一般座標であり

$\left\{\begin{array}{llllllll}q_{1} & q_{2} & q_{3} & q_{4} & q_{5} & q_{6} & q_{7} & q_{8}\end{array}\right\}$

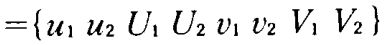

で表される、したがって，運動方程式は次式で表され ろ.

$$
\begin{gathered}
\boldsymbol{M} \ddot{\boldsymbol{q}}+(\boldsymbol{G}+\boldsymbol{C}) \dot{\boldsymbol{q}}+\left(\boldsymbol{K}_{0}+\boldsymbol{K}_{c}\right) \boldsymbol{q} \\
=\dot{\phi} \boldsymbol{f}_{s}+\ddot{\phi} \boldsymbol{f}_{n}
\end{gathered}
$$

ここで、 $\boldsymbol{q}$ は変位ベクトル, $\boldsymbol{M}$ は質量マトリックス, $G$ はジャイロマトリックス, $C$ は減衰マトリックス, $\boldsymbol{K}_{0}$ 注剛性マトリックス， $\boldsymbol{K}_{c}$ は摇動あるいは旋回の角

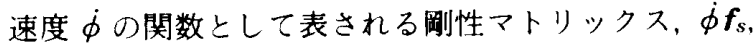
$\ddot{\phi} \boldsymbol{f}_{n}$ は摇動あるいは旋回によって発生する励振力であ る.

理論解析では運動方程式 (33)を用い，固有值と時刻

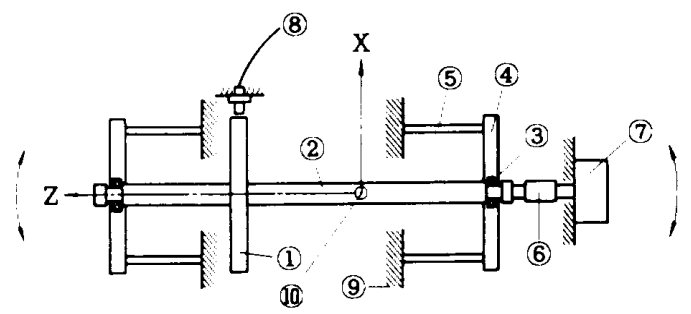

(1)Rotating disk (2)Rotating shaft (3)Ball bearing (4) Bearing housing (5) Elastic rod (6) Silicone rubber coupling (7) Motor (8) Displacement sensor

(9) Frame (

図 3 実験装置概略
歴応答の解析を行った。式(33)の成分を付録に示す。

\section{3. 実験}

$3 \cdot 1$ 実呀装置実験装置の概略を図 3 に示す. 回 転円板(1)(外径 $=100 \mathrm{~mm}$, 厚さ $=14.4 \mathrm{~mm}, \mathrm{SK}$ 鋼) と 回転軸(2)(直径 $=17.5 \mathrm{~mm}$, 軸受間長さ $=249 \mathrm{~mm}$, SK 鋼)から成るロー夕は玉軸受(3)を介して軸受台(4)に取 付けられている. 軸受台(4)(外径 $=100 \mathrm{~mm}$, 内径 $=22$ $\mathrm{mm}$ ，厚さ $=6 \mathrm{~mm}$,アルミ合金)はフレームに取付け られた 4 本の弾性棒(5)(直径 $=1.47 \mathrm{~mm}$, 長さ $=43.4$ $\mathrm{mm}, \mathrm{SK}$ 鋼) から成る等方性ばねによって支持されて いる。ロータはシリコンゴム継手(6)によりモータ(7)に 接続されている.フレーム(9)は中心(10)回りに摇動す る.

\section{$3 \cdot 2$ 実験方法}

（1）固有摇動数の測定摇動させないで、ロー 夕を所定の回転数で回転させ、軸受台(4)を衝撃加振す る. 回転円板(1)の $x$ 方向と $y$ 方向の変位をフレーム(9) に取付けた渦電流式非接触変位計(8)で測定し, FFT を用いてロー夕の各回転数に対する固有摇動数を求め た。

（2）摇動時の時刻歷㐫答䟚定の回転 数で回転させて，フレーム(9)を摇動させる，その時の 回転円板(1)の $x$ 方向と $y$ 方向の時刻歴変位を測定し た。

\section{4. 結果と考察}

軸受台のばね定数と粘性隇衰係数は軸受台単体の加 振実験に上り求め, $k_{x 1}=k_{x 2}=k_{y 1}=k_{y 2}=2.50 \times 10^{4}$ $\mathrm{N} / \mathrm{mm}, c_{x 1}=c_{x 2}=c_{y 1}=c_{y 2}=1.34 \mathrm{~kg} / \mathrm{s}$ とした。本実 験装置の玉軸受部のば权定数は軸受台のばね定数に比 し十分大きいので, $K_{x 1}=K_{x 2}=K_{y 1}=K_{y 2}=k_{x 1} \times 10^{3}$ $\mathrm{N} / \mathrm{mm}$ とした。また，玉軸受部の粘性減衰係数は減衰 マトリックスが比例粘性隇衰となるように $C_{x 1}=C_{x 2}$ $=C_{y 1}=C_{y 2}=1.34 \times 10^{3} \mathrm{~kg} / \mathrm{s}$ とした。 
$4 \cdot 1$ 固有摇功数と固有モード摇動, 旋回がな く $(\dot{\phi}=0)$, ロー夕も回転していない $(\Omega=0)$ 場合の一 次と二次の固有摇動数は，実験結果が $f_{01}=26.0 \mathrm{~Hz}$, $f_{02}=47.0 \mathrm{~Hz}$, 解析結果が $f_{01}=27.3 \mathrm{~Hz}, f_{02}=47.9 \mathrm{~Hz}$ となり，良く一致している。また，一次のモードは回転 軸の両支持部が同相で動く並進モードであり，二次は 回転軸の両支持部が逆相で動くピッチングモードであ る。

図 4 にロータの各回転数に対する振れ回り固有摇動 数の関係を示す。の寒験結果と実線の解析結果は良 く一致している.ロータが回転している場合は, ジャ イロ効果により各次数のモードについて前向きと後向 きの振れ回り固有摇動数が現れる. 特に, 二次のピッ チングモードに対してはジャイロ効果が大きいため， 前向きと後向きの固有摇動数の差は大きくなる，一次 の並進モードについてはジャイロ効果が小さいので, 前向きと後向きの固有摇動数の差は小さくなり, 実験 では一つの固有摇動数として測定された，理論解析に おいても同様の理由で, 图上では固有摇動数曲線がほ とんど重なっている。

軸支持部の質量の影啐を調べるため質量比 $\mu\left(=\mu_{1}\right.$ $\left.=m_{1} / M=\mu_{2}=m_{2} / M\right)$ と固有摇動数との関係を解析 し，結果を図 5 に示す.実線は非回転時, 破線は回転時 (4 $800 \mathrm{rpm})$ である。軸受台と軸受のば权定数は $2.50 \times$ $10^{4} \mathrm{~N} / \mathrm{mm}$ とした。一次のモードは回転軸の両支持部 が同相で動く並進モード（回転軸の支持部と集中質量 も同相)，二次は回転軸の両支持部が逆相で動くピッ チングモード(回転軸の支持部と集中質量は同相), 三 次のモードは回転軸の両支持部が同相で動く並進モー ド(回転軸の支持部と集中質量は逆相), 四次のモード

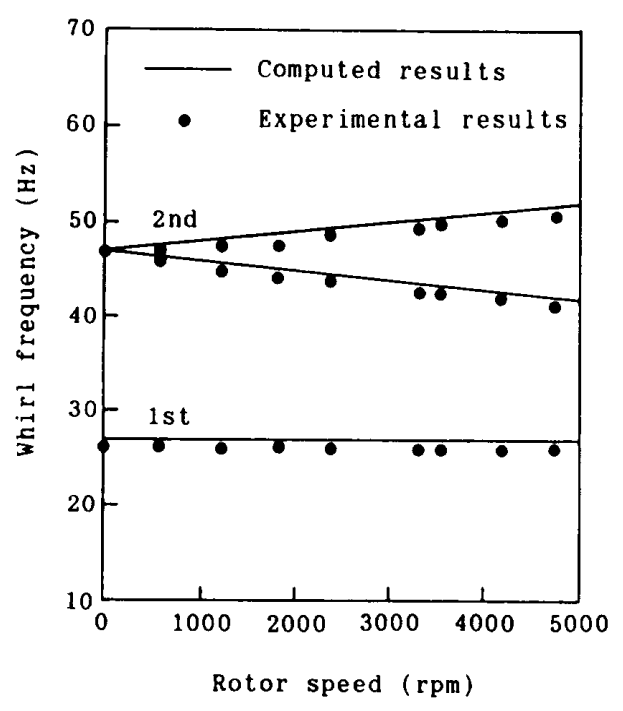

図 4 ロータの回転数と振れ回り固有振動数
は回転軸の両支持部が逆相で動くピッチングモード (回転軸の支持部と集中質量も逆相)である.三次と四 次の固有摇動数は $\mu$ の影響を大きく受け， $\mu$ が大きく なるとそれぞれの固有摇動数は小さくなる。一次と二 次の固有摇動数は $\mu<0.05$ の場合， $\mu$ の影響をほとん ど受けない。これは，一次と二次はロータと支持部の 質量が同相で動き，三次と四次は逆相で動くためと考 えられる。また， $\mu$ が小さい場合は一次・二次と、三

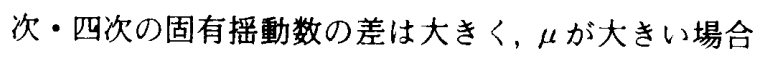
はその差は小さい。

$4 \cdot 2$ 播助時の時刻歴応答 理論解析では, Newmark $の \beta$ 法を用い，時間增分を $\Delta t=0.002 \mathrm{~s}$ と した.また，実験では，摇動による影響のみを調べるた め $5 \mathrm{~Hz}$ 以上の高周波成分はカットした。

図 6 に正弦波で摇動(摇動数 $=1.96 \mathrm{~Hz}$, 振幅 $=1.0$ $\operatorname{deg})$ させた場合の時刻歴応答の一例を示す.実線は解

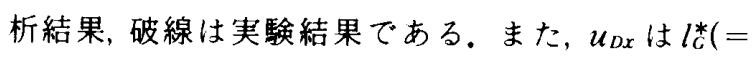
$l_{G} / L$, 摇動中心と回転体の重心の距離)の影響による 回転円板の $x$ 方向変位, $u_{D y}$ はジャイロ効果による $y$ 方向変位である。解析結果と実験結果は良く一致して いる。

図 7 に正弦波で摇動させた場合について，l（変位 振幅との関係を示寸.実線は解析結果, ○、○はそれぞ れ $x$ 方向, $y$ 方向変位の実験結果である。が大きく なると $u_{D x}$ は大きくなるが $u_{D y}$ は変化していない。こ れは㳻が大きくなるとロータに作用する $y$ 軸回りの モーメントが大きくなるのに対して，x軸回りのジャ イロモーメントは変化しないためである.

図 8 に正弦波で摇動させた場合のロー夕回転数と変 位振幅との関係を示す。ロー夕回転数が大きくなると $u_{D y}$ は大きくなるが $u_{D x}$ は変化していない。こ机は口 一夕回転数が大きくなると $x$ 軸回りのジャイロモー

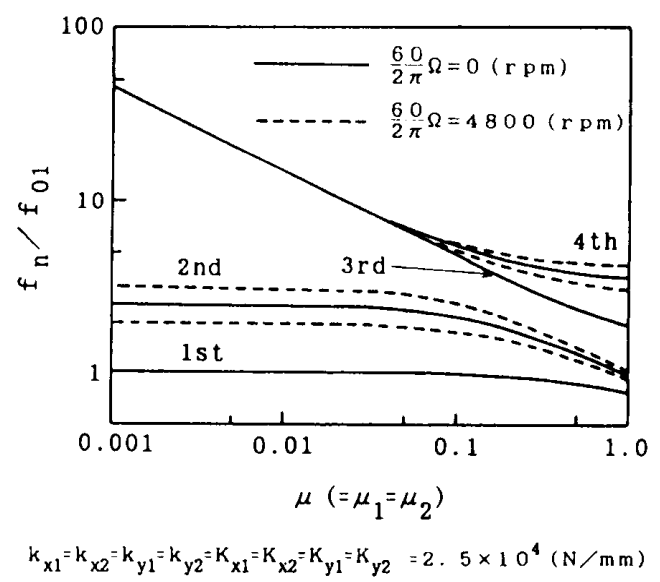

図 5 質量比に対する固有振動数 
メントが大きくなるのに対して,$y$ 軸回りのモーメン トは変化しないためである。

$4 \cdot 3$ 色旋回時の時刻歴応答 急旋回時の変位応 答をシミュレートするため, ステップ入力時 $(\dot{\phi}=0 ; t$ $<0, \quad \dot{\phi}=\pi / 2 \mathrm{rad} / \mathrm{s} ; t \geqq 0)$ の時刻歴応答を理論解析に より求め, 結果を図 9 に示す。高周波成分は二次モ一 ドの前向きと後向き振れ回り固有摇動数の平均值によ るものであり，うなり摇動数はそれぞれの差によるも のである.また, 定常時の変位振幅は $u_{D y} / L=1.51 \times$ $10^{-4}$ となった.

\section{5. 結吾}

摇動中心からある距離だけ離れた位置に設置され， かつ，質量を有する軸受台によって弾性的に支持され た剛性ロータが, 摇動あるいは旋回による基礎励振を

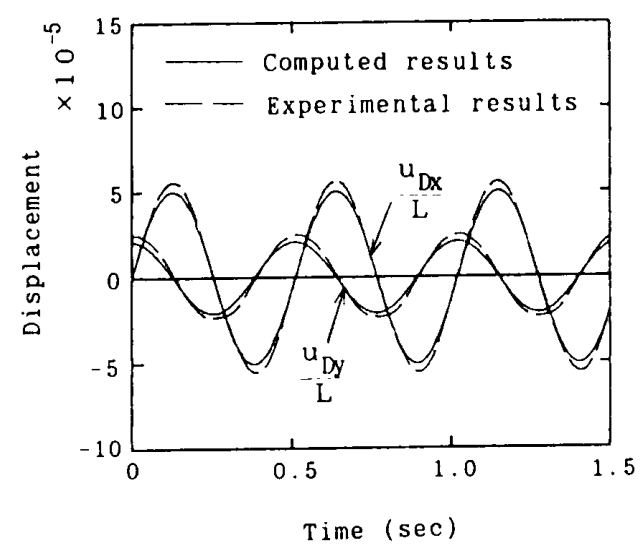

Rotor speed $\frac{60}{2 \pi} \Omega=3600(\mathrm{rm}), \quad t_{\mathrm{G}}^{*}=0.607$. Exciting frequency $\mathrm{f}_{\mathrm{e}}=1.96(\mathrm{~Hz})$, Exciting amplitude $\frac{180}{\pi} \phi_{0}=1.0(\mathrm{deg})$.

図 6 摇動時の回転円板での時刻歴応答

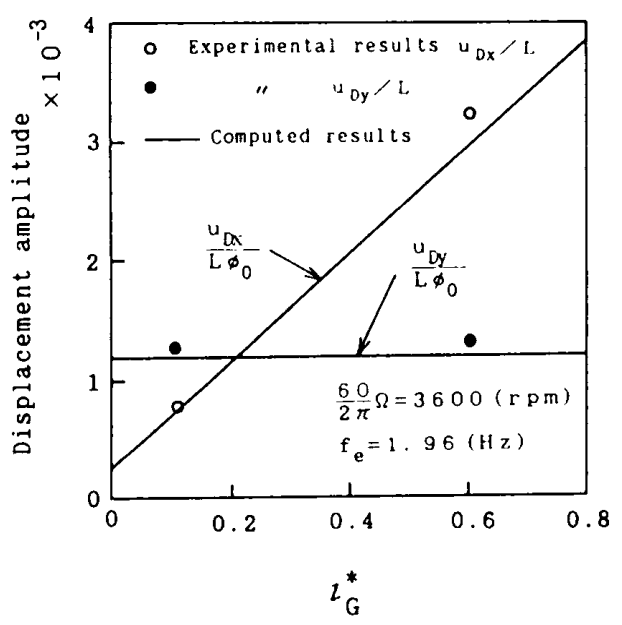

図 7 摇動軸とロー夕重心の距踓に対する変位振幅
受ける場合の運動方程式を等出し，固有值と橓動時の 応答の解析を行った。 また本解析のモデル化と解析プ ログラムの有効性を確かめるために摇動実験を行い, 解析結果と実験結果とが良く一致することを示した。 さらに，このプログラムを用いて急旋回時の応答解析 を行った。その結果, 次のことが明らかになった。

（1）軸受台と軸受の弾性が同程度の場合, 三次と 四次の固有摇動数はロー夕と軸受支持部の質量比に大 きく影響される，一次と二次の固有摇動数は質量比が 小さい場合 $(\mu<0.05)$, 支持部の質量にあまり影響さ れない.

（2）摇動時にロータに作用する摇動軸回りのモー メントは設置距離に比例して増大する。したがって, 回転機械は機体あるいは設備の摇動中心に近い位置に 設置することが望ましい.

\section{付録}

運動方程式 (33)を無次元量を用いて整理した．以下 に無次元量を示す.

支持部の集中質量 $m_{1}, m_{2}$ をロー夕の質量 $M$ を用 い無次元化する.その質量比を次式で表す。

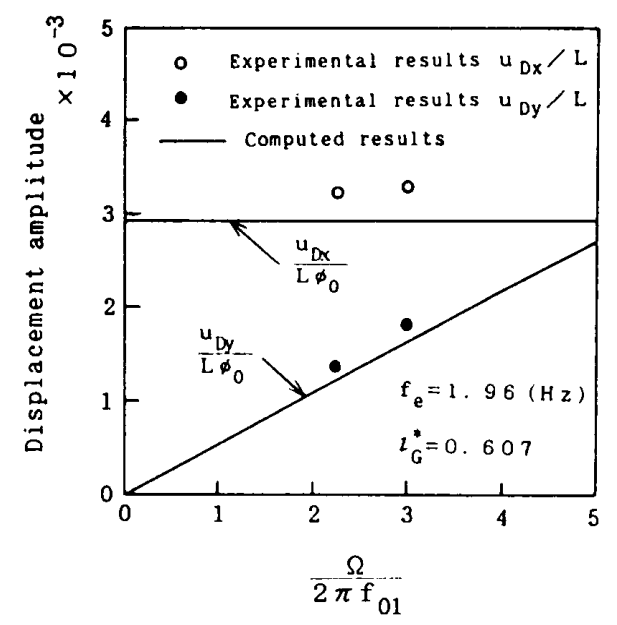

図 8 ロー夕回転数に対する変位振幅

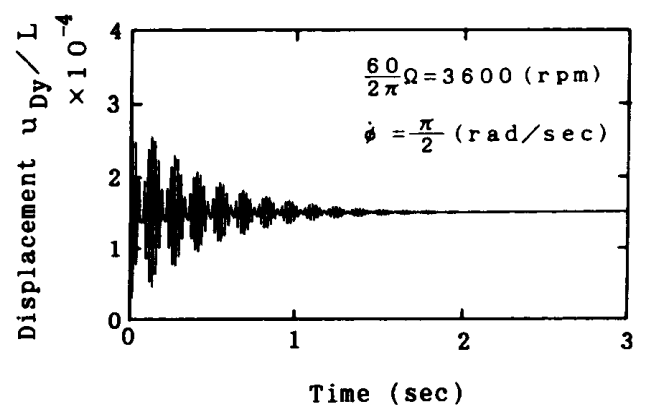

図 9 急旋回時の回転円板での過渡応答 


$$
\begin{aligned}
& \mu_{1}=\frac{m_{1}}{M} \\
& \mu_{2}=\frac{m_{2}}{M}
\end{aligned}
$$

ロータの主軸( $\zeta$ 軸) まわりの回転半径 $R$ とと軸に垂 直な主軸 $\left(\xi, \eta\right.$ 軸) まわりの回転半径 $l_{d}$ を次式で定義 する。

$$
\begin{aligned}
& R^{2}=\frac{J_{p}}{M} \\
& l_{d}^{2}=\frac{J_{d}}{M}
\end{aligned}
$$

長さに関しては，軸受間の長さ $L て ゙$ 無次元化し，そ れぞれ次式で表す。

$$
\begin{aligned}
& l_{1}^{*}=\frac{l_{1}}{L} \ldots \\
& l_{2}^{*}=\frac{l_{2}}{L} \cdots \\
& l_{c}^{*}=\frac{l_{G}}{L} \\
& l_{d}^{*}=\frac{l_{d}}{L} \\
& R^{*}=\frac{R}{L} \\
& u_{1}^{*}=\frac{u_{1}}{L} \\
& u_{2}^{*}=\frac{u_{2}}{L} \\
& U_{1}^{*}=\frac{U_{1}}{L} \\
& U_{2}^{*}=\frac{U_{2}}{L} \\
& v_{1}^{*}=\frac{v_{1}}{L} \\
& l_{2}^{*}=\frac{v_{2}}{L} \\
& V_{1}^{*}=\frac{V_{1}}{L} \\
& V_{2}^{*}=\frac{V_{2}}{L}
\end{aligned}
$$

ばね定数と集中質量との比は，次式で表される周波 数パラメータを用いて表現される。

$$
\begin{aligned}
& \omega_{x 1}^{2}=\frac{k_{x 1}}{m_{1}} \\
& \omega_{x 2}^{2}=\frac{k_{x 2}}{m_{2}} \\
& \omega_{y 1}^{2}=\frac{k_{y 1}}{m_{1}} \\
& \omega_{y 2}^{2}=\frac{k_{y 2}}{m_{2}} \\
& \Omega_{x 1}^{2}=\frac{K_{x 1}}{M_{1}} \\
& \Omega_{x 2}{ }^{2}=\frac{K_{x 2}}{M_{2}}
\end{aligned}
$$

$$
\begin{aligned}
& \Omega_{y 1}^{2}=\frac{K_{y 1}}{M_{1}} \\
& \Omega_{y 2}{ }^{2}=\frac{K_{y 2}}{M_{2}}
\end{aligned}
$$

粘性減衰俰数と集中質量との比を次式で定義する.

$$
\begin{aligned}
& 2 \zeta_{x 1} \omega_{x 1}=\frac{C_{x 1}}{m_{1}} \\
& 2 \zeta_{x 2} \omega_{x 2}=\frac{c_{x 2}}{m_{2}} \\
& 2 \zeta_{y 1} \omega_{y 1}=\frac{C_{y 1}}{m_{1}} \\
& 2 \zeta_{y 2} \omega_{y 2}=\frac{C_{y 2}}{m_{2}} \\
& 2 \zeta_{x 1} \Omega_{x 1}=\frac{C_{x 1}}{M_{1}} \\
& 2 \zeta_{x 2} \Omega_{x 2}=\frac{C_{x 2}}{M_{2}} \\
& 2 \zeta_{y 1} \Omega_{y 1}=\frac{C_{y 1}}{M_{1}} \\
& 2 \zeta_{y 2} \Omega_{y 2}=\frac{C_{y 2}}{M_{2}}
\end{aligned}
$$

運動方程式(33)の変位ベクトルを無次元量を用いて 表せば次式となる。

$$
\boldsymbol{q}=\left\{u_{1}^{*} u_{2}^{*} U_{1}^{*} U_{2}^{*} v_{1}^{*} v_{2}^{*} V_{1}^{*} V_{2}^{*}\right\}^{T}
$$

質量マトリックス $\boldsymbol{M}$ の $i$ 行 $j$ 列成分を $M_{i j}$ とすると 各成分は次式で表される，以後，記述されていない成 分はすべて褰である。

$$
\begin{aligned}
& M_{11}=M_{22}=M_{55}=M_{66}=1 \cdots \cdots \ldots \ldots \ldots \ldots \ldots \\
& M_{33}=M_{44}=M_{77}=M_{88}=l_{1}^{*} l_{2}^{*}+l_{d}^{*^{2}} \cdots \cdots \cdots \cdots \\
& M_{34}=M_{43}=M_{78}=M_{87}=\frac{1}{2}\left(l_{1}^{*^{2}}+l_{2}^{*^{2}}\right)-l_{d}^{*^{2}}
\end{aligned}
$$
ジャイロマトリックスの各成分は次式で表される。

$$
\begin{aligned}
& G_{37}=G_{48}=G_{74}=G_{83}=\Omega R^{* 2} \\
& G_{38}=G_{47}=G_{73}=G_{84}=-\Omega R^{*^{2}}
\end{aligned}
$$

㴊性マトリックス $\boldsymbol{K}_{0}$ の $i$ 行 $j$ 列の成分を $K_{0_{i j}}$ とす ると各成分は次式で表きれる。

$$
\begin{aligned}
& K_{011}=\frac{1}{\mu_{1}} \Omega_{x 1}^{2}+\omega_{x 1}^{2} \\
& K_{013}=-\frac{1}{\mu_{1}} \Omega_{x 1}{ }^{2} \\
& K_{022}=\frac{1}{\mu_{2}} \Omega_{x 2}^{2}+\omega_{x 2}^{2} \\
& K_{024}=-\frac{1}{\mu_{2}} \Omega_{x 2}{ }^{2} \\
& K_{031}=-\Omega_{x 1}^{2} \\
& K_{033}=\Omega_{x 1}^{2} \\
& K_{042}=-\Omega_{x 2}^{2} \\
& K_{044}=\Omega_{x^{2}}^{2} \\
& K_{055}=\frac{1}{\mu_{1}} \Omega_{y 1}{ }^{2}+\omega_{y 1}{ }^{2}
\end{aligned}
$$




$$
\begin{aligned}
& K_{057}=-\frac{1}{\mu_{1}} \Omega_{y 1}{ }^{2} \\
& K_{066}=\frac{1}{\mu_{2}} \Omega_{y 2}{ }^{2}+\omega_{y 2}{ }^{2} \\
& K_{068}=-\frac{1}{\mu_{2}} \Omega_{y 2}^{2} \\
& K_{075}=-\Omega_{y 1}^{2} \\
& K_{077}=\Omega_{y 1}{ }^{2} \\
& K_{086}=-\Omega_{y 2}^{2} \\
& K_{088}=\Omega_{y 2}^{2}
\end{aligned}
$$

减衰マトリックス $\boldsymbol{C}$ の各成分 $C_{i j}$ は次式で表される。

$$
\begin{aligned}
& C_{11}=\frac{2 \zeta_{x 1}^{\prime} \Omega_{x 1}}{\mu_{1}}+2 \zeta_{x 1} \omega_{x 1} \\
& C_{13}=-\frac{2 \zeta_{x} i \Omega_{x 1}}{\mu_{1}} \\
& C_{22}=\frac{2 \zeta_{x 2} \Omega_{x 2}}{\mu_{2}}+2 \zeta_{x 2} \omega_{x 2} \\
& C_{24}=-\frac{2 \zeta_{x 2} \Omega_{x 2}}{\mu_{2}} \\
& C_{31}=-2 \zeta_{x i} \Omega_{x 1} \\
& C_{33}=2 \zeta_{x 1} \Omega_{x 1} \\
& C_{42}=-2 \zeta_{x 2}{ }^{\prime} \Omega_{x 2} \\
& C_{44}=2 \zeta_{x^{\prime}}^{\prime} \Omega_{x 2} \\
& C_{55}=\frac{2 \zeta_{y 1} \Omega_{y 1}}{\mu_{1}}+2 \zeta_{y 1} \omega_{y 1} \\
& C_{57}=-\frac{2 \zeta_{y i} i \Omega_{y 1}}{\mu_{1}} \\
& C_{66}=\frac{2 \zeta_{y 2} \Omega_{2 y 2}}{\mu_{2}}+2 \zeta_{y 2} \omega_{y 2} \\
& C_{68}=-\frac{2 \zeta_{y 2}^{\prime} \Omega_{y 2}}{\mu_{2}} \\
& C_{i 5}=-2 \zeta_{y 1} i \Omega_{y 1} \\
& C_{77}=2 \zeta_{y 1} \Omega_{y 1} \\
& C_{86}=-2 \zeta_{y 2}^{\prime} \Omega_{y 2}
\end{aligned}
$$

$C_{88}=2 \zeta_{y 2} \Omega_{y 2}$

摇動あるいは旋回角速度 $\dot{\phi}$ の関数として表される剛 性マトリックス $\boldsymbol{K}_{c}$ の各成分 $K_{c i j}$ は次式で表される。

$$
\begin{aligned}
& K_{c 11}=K_{c 22}=-\dot{\phi}^{2} \\
& K_{c 33}=K_{c 44}=-\left(l_{1}^{*} l_{2}^{*}+l_{c}^{*^{2}}\right) \dot{\phi}^{2} \\
& K_{c 34}=K_{c 43}=\left\{l_{c}^{*^{2}}-\frac{1}{2}\left(l_{1}^{* 2}+l_{2}^{* 2}\right)\right\} \dot{\phi}^{2} \\
& K_{c 77}=K_{c 88}=-R^{*^{2}} \dot{\phi}^{2} \\
& K_{c 78}=K_{c 87}=R^{*^{2}} \dot{\phi}^{2}
\end{aligned}
$$

励振力ベクトル $\dot{\phi} \boldsymbol{f}_{s}, \ddot{\phi} \boldsymbol{f}_{n}$ はそれぞれ次式で表される。

$$
\begin{aligned}
& \dot{\phi} f_{s 7}=-\dot{\phi} \Omega R^{* 2} \\
& \dot{\phi} f_{\mathrm{s} \mathrm{B}}=\dot{\phi} \Omega R^{* 2} \\
& \ddot{\phi} f_{n 1}=\ddot{\phi}\left(l_{1}^{*}-l_{c}^{*}\right) \\
& \ddot{\phi} f_{n 2}=-\ddot{\phi}\left(l_{2}^{*}+l_{c}^{*}\right) \\
& \ddot{\phi} f_{n 3}=\ddot{\phi}\left\{\frac{1}{2} l_{2}^{*}\left(l_{1}^{*}-l_{2}^{*}\right)-\frac{1}{2} l_{c}^{*}\left(l_{1}^{*}+l_{2}^{*}\right)+l_{d}^{* 2}\right\} \\
& \ddot{\phi} f_{n 4}=-\ddot{\phi}\left\{-\frac{1}{2} l_{1}^{*}\left(l_{1}^{*}-l_{2}^{*}\right)+\frac{1}{2} l_{c}^{*}\left(l_{1}^{*}+l_{2}^{*}\right)\right. \\
& \left.+l_{d}^{* 2}\right\}
\end{aligned}
$$

\section{文献}

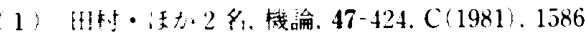

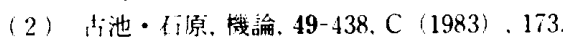

(3) 佃 - 们原機論, 50-451. C (1984)，470.

(4) 我妻・各藤, 機論, 50-460. C (1984)，2242.

(5) Soni. A. H. and Srinivasan. V.. Trans. A.SME, J. lib Acoust. Stress Relimb. Des., 105 (1983) , 449-455.

(6) Samali. B. Kim, K. B. and Yang. J. N., ASCE. J. Eng. Mech. 112-6 (1986), 550-565.

(7) Sakata. M., Kimura, K.. Park. S. K. and Ohnabe. H.. J. Sintend lik. . 131-3 (1989) , 417-430.

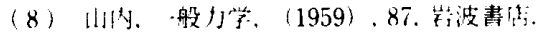

